\title{
Wholistic Management Education (WME): Theorizing the Contextualized Applicability of Transformative Learning in Management Education Discourse
}

\author{
Naveed Yazdani ${ }^{1}$, Hassan S. Murad ${ }^{1}$, Aleena Shuja ${ }^{1 *}$
}

\begin{abstract}
Traditional management education discourse is in crisis. It does not prepare students to face real world complexities and challenges because it is devoid of context and historicity and localness. It focuses narrowly on the means and not ends of managing and organizing. To address these glaring and gaping fissures between concepts and reality. This paper utilizes Mezirow's theory of transformative learning approach in management education so that the future managers are on course for individual transformation. Later developments in the transformative learning theory connecting it with extra-rational thinking, multiple ways of knowing and critically evaluating social dynamics are also incorporated so that the individual transformation leads to more broader collective transformation. The discursive interplay between texts, actions and discourses are captured in the proposed Wholistic Management Education (WME) model. The model's validity and its relation with Discourse Analysis and Critical Discourse Analysis are briefly discussed along with future research directions.
\end{abstract}

Keywords: Transformative Learning, Management Education, Wholistic Management Education, Discourse Analysis, Critical Discourse Analysis, Critical Reflection.

\section{Introduction}

The objectivist positivistic paradigm of learning (Bredo \& Feinberg, 1982) is an outcome of the Western rational tradition. According to this tradition reality exists independently, knowledge is objective, knowledge standards are fixed and language merely acts as a conduit for conveying knowledge (Mezirow, 1996). The validity of this type of knowledge is established through empirical data analysis and hypothesis testing. This type of learning which (Habermas, 1978, 1984) described as instrumental learning is concerned with controlling and manipulating environment, improving prediction and performance, assessment of truth claims, and formal subject-wise education. Its underlying logic and rational is hypothetical-deductive while its methodology is strictly positivistic and empirical (Mezirow, 1994, 2000a, 2003).

https://doi.org/10.30537/sijmb.v4i1.103

${ }^{1}$ University of Management and Technology, Lahore Pakistan

* Corresponding Author: aleena.shuja@umt.edu.pk 
Naveed Yazdani et. al. / Wholistic Management Education (WME): Theorizing the Contextualized Applicability of

Seven management researchers who have published in top tier academic management journals including Academy of Management Review were interviewed to find out the sources of their research ideas (Byron \& Thatcher, 2016). The study revealed multiple sources. However direct observations and attempting to solve real-world business issues were at the bottom of the list of such sources. This implies that real life management practices rarely fuel academic management research. This gap between management theories and practices Sandberg and Tsoukas (2011) is attributed to the above highlighted objectivistic onto-epistemic assumptions underlying academic management education discourse. The real life practice of management is far more fuzzy and entangled with humans, objects, technology, systems, processes and environment. The socio material entanglement Carlile, Nicolini, Langley, and Tsoukas (2013) of real world organizational problems separates them from the sterile management journal articles and texts which stress rigor of methodology over applicability of knowledge produced.

Western civilization's ascendency since $19^{\text {th }}$ century in politics, economics, military power and scientific and technological endeavors is no secret. Throughout most of the post-Enlightenment period the rest of the world, especially the Asian cultures imported Western practices and ideas to give legitimacy to their own discourses of various natures. Education was no exception to this general rule (Liu, 2011). That is why international education is largely dominated by a US led cartel of a few countries such as UK, France, Australia, Germany and Canada. The cartel supports globalization of education because it has and is expected to continue to open up a huge upsurge in demand of their education by foreign students. The number of international students in US has swelled to 3.7 million from about 1 million over the last about 4 decades. Despite a strong competition developing in some South and North Eastern countries the international pecking order in higher education is expected to hold in the coming decades.

Joullié (2016), explores the philosophical roots of the above mentioned dominance of Western thought in management education discourse. His research shows that with the exception of Art of War by Sun Tzu, Eastern philosophy and thought has little influence on management education. He identifies six main Western philosophic themes which have found their way in the global management education discourse (Joullié \& Spillane, 2015):

1. Heroism (Power, rewards, rules, MBO, performance appraisal systems)

2. Rationalism (Universality of management, reason based planning, analysis)

3. Positivism (Value-neutral research and knowledge, inductive theories, determinism, objectivity evidence-based-management)

4. Romanticism (Passion, innovation, creativity, subjectivity, will, entrepreneurship)

Sukkur IBA Journal of Management and Business | Volume 4 No. 1 January - June 2017 @ Sukkur IBA University 
Naveed Yazdani et. al. / Wholistic Management Education (WME): Theorizing the Contextualized Applicability of

5. Existentialism (Freedom, accepting responsibility for own actions, decision making)

6. Postmodernism (Virtual more than real, knowledge constructed socially, narratives, multiculturalism, linguistic deconstruction)

The above discussion places business education in the objectivist traditional paradigm of teaching which draws from instrumental ways of learning. It also highlights why business education's curricula are more or less the same across the globe (Agasisti \& Johnes, 2015; Mintzberg, 2004). The contemporary educationists Gardner and Kelly (2008) believe that traditional management education is not delivering (Ghoshal, 2005; Mintzberg, 2004; Slater \& Dixon-Fowler, 2010). It is this 'crisis of pedagogy' which is responsible for letting the students to miss learning from complex and ambiguous situations (Nicolaides, 2015). Scholars seem to agree that universality of management theories (Arum \& Roksa, 2011; Pfeffer, 2013; Willmott, 2013), their too much market oriented focus (Bennis \& O'Toole, 2005) and their short-term 'unwise' profit motive (Baden \& Higgs, 2015) is causing financial crises and, rising number of corporate scandals in society. In fact most of the business leaders involved in these scandals had MBA from top tiered business schools (Coryell, 2013). Some of the most prominent management education scholars call for 'creative destruction' of business schools and their 'scientific' (Mintzberg, 2004) teaching practices (Pettigrew \& Starkey, 2016). Business schools are therefore under pressure to transform their teaching discourses (Isopahkala-Bouret, 2015; Parker \& Guthrie, 2010) so that their products or students are also transformed to face the challenges of real life.

The above mentioned deficiencies of traditional management education along with "a documented gap between the skills needed for many business and management careers and those acquired during a student's academic career" Ungaretti, Thompson, Miller, and Peterson (2015) in business schools are main drivers asking business school education to undergo transformation. Transformative learning is a well-respected theory of adult education (Mezirow \& Taylor, 2011) but the application of its various developments in the context of management education is not much researched especially outside the North American context. The prime purpose of this paper is to conceptualize a theoretical framework in the form of a model based on cutting edge transformative learning theory development under the fold of management education in different contexts. The main output of this paper is therefore, a Wholistic Management Model (WME) model of teaching suggested to be employed by management education imparting institutions.

One of the ways to define wholeness in management education is what Baden and Higgs (2015) term as wisdom. According to them the essence of wisdom lies in clearly prioritizing ends (societal benefits and social well-being) over means (instrumental monetary goals and objectives). Failure to base organizational frameworks and

Sukkur IBA Journal of Management and Business | Volume 4 No. 1 January - June 2017 @ Sukkur IBA University 
Naveed Yazdani et. al. / Wholistic Management Education (WME): Theorizing the Contextualized Applicability of

management education curricula (and ultimately organizational practices) on this prioritization is what accounts for lack of wisdom in business education. In their notion of wisdom in management education (Baden \& Higgs, 2015) envisage an inextricable relationship between individual, society, culture and environment and focus on the long term societal and ecological benefits over the short term material gains only.

The wholeness of management education can also be related with (Kagan, 2007) p. 245-247) presentation of two types of scientists through the metaphors of 'hunters' and 'butterfly chasers'. Hunters represent the physicists, chemists and mathematicians. They have little tolerance for ambiguity but great affinity for facts, proving hypothesis and building reliable relations. The butterfly chasers are historians and humanities specialists who like to pursue fuzzy and uncertain questions and are comfortable with ambiguity. Kagan places social scientists close to the butterfly chasers while biologists stand next to the hunters. He however laments that "sadly, the hunters with rifles are driving the children chasing butterflies from the forest (of knowledge and learning), even though rifles are not a very good way to catch butterflies".

This paper has five sections. Section 1 has already presented major scholarly critique on management education and has also highlighted the need for a transformative learning based wholistic management education or WME. Section 2 briefly surveys the literature on transformative learning covering its Mezirownian and nonMezirownian shades and in doing so constructs 5 sub-discourses of transformative education (TME) under the main discourse of management education. Section 3 is devoted to construction of the WME model. It is here that the 5 sub-discourses constructed in Section 2 are linked with each other as antecedents to the processes and outcomes of the model which are interactively embedded in localness and Contextuality (organizations, society, culture and environment). Section 4 briefly describes the methodology employed in this paper and discusses how Discourse Analysis and Critical Discourse Analysis construct and analyse Section 1 and 2. Section 5 briefly discusses the validity of WME model in the spirit of its contextualized applicability in management education along with future research directions.

\section{Literature Review}

The main critique on management education discussed in the previous section clearly merits transformation of contemporary ways of imparting management education in terms of developing 'wise' managers who not only focus on financial returns but also on the longer term and larger objectives and contexts in which they are embedded. The contexts comprise organizations, society, culture and environment. This section therefore, explores the developments and evolution of Mezirow's transformative learning theory over the last 4 decades. These developments are presented as various transformative management education (TME) 'levels'. It is the connectivity among

Sukkur IBA Journal of Management and Business | Volume 4 No. 1 January - June 2017 @ Sukkur IBA University 
Naveed Yazdani et. al. / Wholistic Management Education (WME): Theorizing the Contextualized Applicability of

these levels with one another and the immediate and distant context which lies at the heart of WME model proposed later.

\subsection{Transformative Learning}

Over the past four decades transformative learning has moved from a mere theory to emerge as a concrete paradigm in higher education (Mezirow, 1989, 1991, 1997, 2003; Mezirow \& Marsick, 1978). This development has however not occurred in the field of business education but mainly in the areas of healthcare education and arts related fields (Coryell, 2013; Jarvis \& Burr, 2011; Morris \& Faulk, 2012).

The 'first wave' theories of transformative learning represent points of departure from Mezirow's theory by developing the spiritual, emotional, relational and contextual perspective in it's purely rationality orientation. The 'second wave' of theory development seeks to integrate the rational with extra-rational to formulate a "more wholistic perspective" (Gunnlaugson, 2008) of transformative learning theory.

Covering a period of 20 years, (Taylor, 1997; E. W. Taylor, 2007) has undertaken two meta-analysis reviews of transformative learning literature. He finds transformative learning to be a "popular area of research in the field of adult education" as indicated by notable increase in the number of publications and bi-annual international conferences in the area. Transformative learning till present time is not empirically studied outside of North American educational context (Fisher-Yoshida, Geller, \& Schapiro, 2009). The relation of transformative learning with social entrepreneurial skills (Plaskoff, 2012), design of some MBA courses (Hoover, Giambatista, Sorenson, \& Bommer, 2010; Mayo, Kakarika, Pastor, \& Brutus, 2012) and cross cultural management education (Szkudlarek, McNett, Romani, \& Lane, 2013) is emerging through some individual studies. There are a few generalized and sporadic studies connecting spirituality with transformative learning (Lawrence, Taylor, \& Cranton, 2012; Newman, 2012) but exploration of its possible connection with specific spiritual knowledge grounded in religiosity is not studied extensively. This probably explains why some scholars like (Tisdell, 2012) feel that big questions such as meaning of life, universe and, love and death are still ignored in transformative learning research.

A six year review (2002-2007) of the top four ranked Management Learning \& Education (MLE) journals by (Rynes \& Brown, 2011) shows that they are increasingly publishing articles making the contention that "good teaching is no longer good enough" for contemporary societal needs. The MLE journals call for transformation of teaching so that the voids created by traditional teaching paradigm are filled (Currie \& Pandher, 2013).

At the heart of Mezirow's transformation theory lays the self-reflective discourse where individuals engage in active dialogue with self and others for better understanding of the meaning of an experience. He also identifies that values like equality, social justice, tolerance, freedom of expression and rationality are

Sukkur IBA Journal of Management and Business | Volume 4 No. 1 January - June 2017 @ Sukkur IBA University 
Naveed Yazdani et. al. / Wholistic Management Education (WME): Theorizing the Contextualized Applicability of

prerequisite for engaging in a reflective discourse undertaken for understanding meanings (Mezirow, 2000b). This implicitly implies that transformative learning is better suited for more advanced and developed societies where democratic norms underpin the educational, legal, moral and political societal discourse. (Mezirow, 2000b) acknowledges that free and full participation in the reflective discourse would not be possible in homeless, hungry, destitute, threatened, frightened and sick adults. Mezirow however sees this as an opportunity for transformative learning to create and foster social justice in less developed and non-democratic societies.

The inclusion of learning context and situation in the process-focused Mezirow's theory is another development which has occurred since the last decade and a half (Mezirow, 2006). Others have also identified implicit restriction on Mezirow's transformative learning process imposed by oppressive elements of a capitalistic society. They argue that by ignoring analysis of hegemonic and power assumptions critical reflection becomes merely apolitical reflection without the ability to transform individuals and society (Brookfield \& Mezirow, 2000). Transformative learning focuses not only on the cognitive but also the emotional and social aspects in which the cognitive self is embedded (Kegan, 2009). In the quest to understand what actually transforms when transformative learning takes place, scholars such as (Illeris, 2014) define it as a learning which "comprises all learning that implies changes in the identity of the learner".

The following four overlapping but distinct streams or what (Cranton \& Carusetta, 2004) calls four lenses or perspectives in the evolution of transformative learning theory and practice are identified from the above discussion.

The first approach is Mezirow's cognitive/rational perspective where transformation through rational critical reflection happens as a ten-step process starting from a 'disorienting' experience and culminating in transformation of a set of uncritically assimilated assumptions of one's beliefs (Mezirow, 1985, 1989, 1991, 2006). The second view is the extra rational/deep psychology perspective emphasizing the imaginal, spiritual, emotive, symbolic, and art-based sides of learning (Dirkx, 1998; Lawrence et al., 2012; Tisdell, 2000). At the heart of this perspective lie the integration of subconscious images and symbols with consciousness. The third approach is the structural developmental perspective which defines transformation as a structural shift in the epistemologies used for learning. Transformation occurs by recognizing the limitations of previous epistemology or meaning making ways (Daloz, 2012; Kegan, 2009).

The first three approaches are concerned with psychological development of the individual (Stevens-Long, Schapiro, \& McClintock, 2012). The fourth approach is the social emancipatory perspective underpinned by (Freire, 1970) based social critique attacking oppression and taking social action in the backdrop of transformative learning (Brookfield \& Mezirow, 2000). This approach targets social transformation.

Sukkur IBA Journal of Management and Business | Volume 4 No. 1 January - June 2017 @ Sukkur IBA University 
Naveed Yazdani et. al. / Wholistic Management Education (WME): Theorizing the Contextualized Applicability of

It is in this context that "I" and "We" are brought together in the understanding of transformative learning at individual and social levels. It is this perspective which sharply differentiates between reflection and critical reflection. This context remains loyal to the Critical Social Theory of Frankfurt School and considers critical reflection as a critique on the ideology of capitalism and its hegemonic assumptions (Brookfield \& Mezirow, 2000). Transformative learning as a whole person learning would entail changes in the first three individual transformation perspectives described above. The fourth level perspective change is geared toward social rather than individual level.

\subsection{Contextuality}

Rationality, the mainstay of Mezirow's transformation theory is a typical Western concept based on the Cartesian Dualism assuming the split between mind and matter. The individualism resulting from Newtonian and Darwinian science whereby human beings are an accidental by-product of some uncontrolled evolutionary process leaves no role for humans in the bigger questions pertaining to his/her purpose and place in the overall scheme of things. This philosophic and scientific thought revolution of $17^{\text {th }}$ century is considered to have "wrenched human beings from their familiar social and religious context (and) thrust (them) headlong into the 'I-centered culture"' (Zohar, 1990).

However, studies like (Kokkos, 2014; Merriam \& Mohamad, 2000; Merriam \& Ntseane, 2008) highlight the impact of difference in discourse of language, culture, history, religion and politics as determinant of variance in the learning processes within different contexts.

The traditional management education paradigm is what (Caza \& Brower, 2015) call the "formal curricula" based education. For them the informal curricula which consists of all elements of a business school/learning environment that are not considered part of the declared curricula are, however, equally important. The elements of informal curricula include but are not limited to guest speakers, free or discounted subscription of business newspapers, magazines and journals and, presence of a student job placement center. Not unlike (Cranton \& Carusetta, 2004), they also advocate integrating the features of formal and informal curricula to bring about transformation through management education. Table 1 captures the main differences between formal and informal curricula. 
Naveed Yazdani et. al. / Wholistic Management Education (WME): Theorizing the Contextualized Applicability of

\begin{tabular}{|c|c|c|}
\hline \multicolumn{3}{|c|}{ Table 1: Some Features of Formal and Informal Curricula } \\
\hline Features & Formal Curricula & Informal Curricula \\
\hline Ownership & $\begin{array}{l}\text { With faculty and education } \\
\text { administrators }\end{array}$ & With students \\
\hline Nature & $\begin{array}{l}\text { Standardized, stated, explicit and } \\
\text { assessable activities }\end{array}$ & $\begin{array}{l}\text { Non-standardized, non- } \\
\text { stated, implicit and non- } \\
\text { assessed activities }\end{array}$ \\
\hline Visibility & $\begin{array}{l}\text { Visible in the form of lectures, } \\
\text { course outlines, grades, diplomas, } \\
\text { degrees, internships. Essential to } \\
\text { attend }\end{array}$ & $\begin{array}{l}\text { Invisible and informal } \\
\text { activities where attendance } \\
\text { is not essential and } \\
\text { compulsory }\end{array}$ \\
\hline Objectives & $\begin{array}{l}\text { Explicit in the form of technical } \\
\text { skills building }\end{array}$ & $\begin{array}{l}\text { Implicit experiences which } \\
\text { are accumulated over and } \\
\text { above the formal curricula }\end{array}$ \\
\hline Results & $\begin{array}{l}\text { Building of standardized } \\
\text { academic/technical skills }\end{array}$ & $\begin{array}{l}\text { Comprises of idiosyncratic } \\
\text { and unique student } \\
\text { experiences }\end{array}$ \\
\hline
\end{tabular}

\subsection{From Transformative to Whole Person Learning}

Efforts to formulate a unified theory of transformative learning are still in progress. Scholars feel that the endeavour is fraught with many constraints and difficulties. One such constraint is the tendency to think in dualist modes despite a plethora of theoretical perspectives on transformation. It is because of dualism inherent in scholarly thinking that transformative learning is looked upon in either/or ways: a focus on rationality or extra rationality, individual or collective learning, organizational or societal learning, autonomous or relational learning, universal or contextual learning. The real challenge lies in understanding that many of these multiple perspectives may not be mutually exclusive but can coexist and change under different contexts and circumstances (Taylor \& Cranton, 2012). The collapsing of dualism would pave way for transformative learning to assume the stature of wholistic learning because it would entail the imparting of "cognitive, emotional, and social skills" or what (Barbera, Bernhard, Nacht, \& McCann, 2015) call the whole-person learning. Scholars like (O'Sullivan, Taylor, \& Cranton, 2012) feel that a leap from traditional to transformative education is a major challenge confronting 21 st century universities. For him transformative education would cause "a deep structural shift in the basic premise of our thoughts, feelings, and actions" (p. 175).

Putting the above definition of transformative education in the context of management education formulates the construct which this paper terms 'transformative management education' (TME). TME would inculcate deep structural shift in the basic premises of thoughts, feelings, and actions so that understanding about self and context and relation with self and others is seen in new ways. It would connect management students with

Sukkur IBA Journal of Management and Business | Volume 4 No. 1 January - June 2017 @ Sukkur IBA University 
Naveed Yazdani et. al. / Wholistic Management Education (WME): Theorizing the Contextualized Applicability of

their own selves, others, social and natural environments and also empowering them to understand hegemonic power relations underpinning issues of class, race, and gender. This level of transformation unlocks the minds to envision alternative ways of living and to feel responsible for long term societal challenges.

Four perspectives of transformative learning have already been discussed. Table 2 summarizes Stevens-Long, (Stevens-Long et al., 2012) extension of that discussion into four perspectives or levels of transformative education.

Table 2: Four Levels of TME

\begin{tabular}{|c|c|c|}
\hline TME Level & Major Proponents & $\begin{array}{l}\text { Transformative Learning } \\
\text { Inducing Pedagogical Practices } \\
\text { \& Interventions }\end{array}$ \\
\hline $\begin{array}{l}\text { TME Level } 1 \\
\text { (cognitive/rational } \\
\text { perspective) }\end{array}$ & $\begin{array}{l}\text { Mezirow \& } \\
\text { Cranton }\end{array}$ & $\begin{array}{l}\text { Ways of fostering critical } \\
\text { reflection } \\
\text { Dialogues on past experiences } \\
\text { Intentional introduction of a } \\
\text { disorienting dilemma }\end{array}$ \\
\hline $\begin{array}{l}\text { TME Level } 2 \text { (Extra- } \\
\text { rational/deep psychology } \\
\text { perspective) }\end{array}$ & Dirkx, Tisdell & $\begin{array}{l}\text { Guided intrapersonal dialogue } \\
\text { with subconscious } \\
\text { Group activities leading to } \\
\text { exploration of subconscious } \\
\text { Activities encouraging } \\
\text { integration of conscious and } \\
\text { subconscious through art, } \\
\text { symbol, images and } \\
\text { imagination }\end{array}$ \\
\hline $\begin{array}{l}\text { TME Level } 3 \text { (Structural } \\
\text { developmental } \\
\text { perspective) }\end{array}$ & Kegan, Daloz & $\begin{array}{l}\text { Activities encouraging } \\
\text { knowing through different } \\
\text { epistemologies } \\
\text { Connected and separate } \\
\text { knowing activities under a right } \\
\text { mix of challenge and } \\
\text { affirmation by the faculty }\end{array}$ \\
\hline $\begin{array}{l}\text { TME L:evel } 4 \text { (Social } \\
\text { emancipatory perspective) }\end{array}$ & Frier, Brookfield & $\begin{array}{l}\text { Critical pedagogy } \\
\text { Feminist view point } \\
\text { Constructivism }\end{array}$ \\
\hline
\end{tabular}

The wholeness debate is gaining momentum in industrialized Western countries which are witnessing the emerging neo-spiritual or post-secular age. Many scholars like (C. Taylor, 2007) believe that objectivism's hold on sciences and philosophy is slipping towards a 'subjective turn' - shift from external to internally-guided life. The main objective of WME model presented in the following section is not merely shifting the

Sukkur IBA Journal of Management and Business | Volume 4 No. 1 January - June 2017 @ Sukkur IBA University 
Naveed Yazdani et. al. / Wholistic Management Education (WME): Theorizing the Contextualized Applicability of

focus of management education from external/objective paradigms towards internal/subjective paradigm but to fuse the two with one another and the context in such a way that 'whole person' managers are produced in business schools.

\section{The Wholistic Management Education (WME) Model}

The WME model (Figure 1) combines the traditional objectivistic (termed as Level Zero), rational based Mezirow's transformative learning theory and, its key other developments into one 'whole' model. Inculcating extra-rationality and learning from multiple ways of knowing are therefore envisaged to be imparted to management students as crucial skills along with their ability to be analytical. Critical reflection on one's own taken for granted assumptions about reality is the mainstay of Mezirow's theory. But critically reflecting and challenging the social status quo is typically a late development in the theory and forms an integral part of WME model because it equips management students to challenge and problematize the issues of power, dominance and imbalance in the organizational and societal discourses with which they seem unconnected by the one-sided traditional management education. The model fully takes into account the organizational, societal and cultural norms of different contexts and is therefore not prescriptive in nature. It has the flexibility to be applied equally successfully in Western, Eastern or other contexts because it does not prescribe and promote a particular way of value system and ethicality.

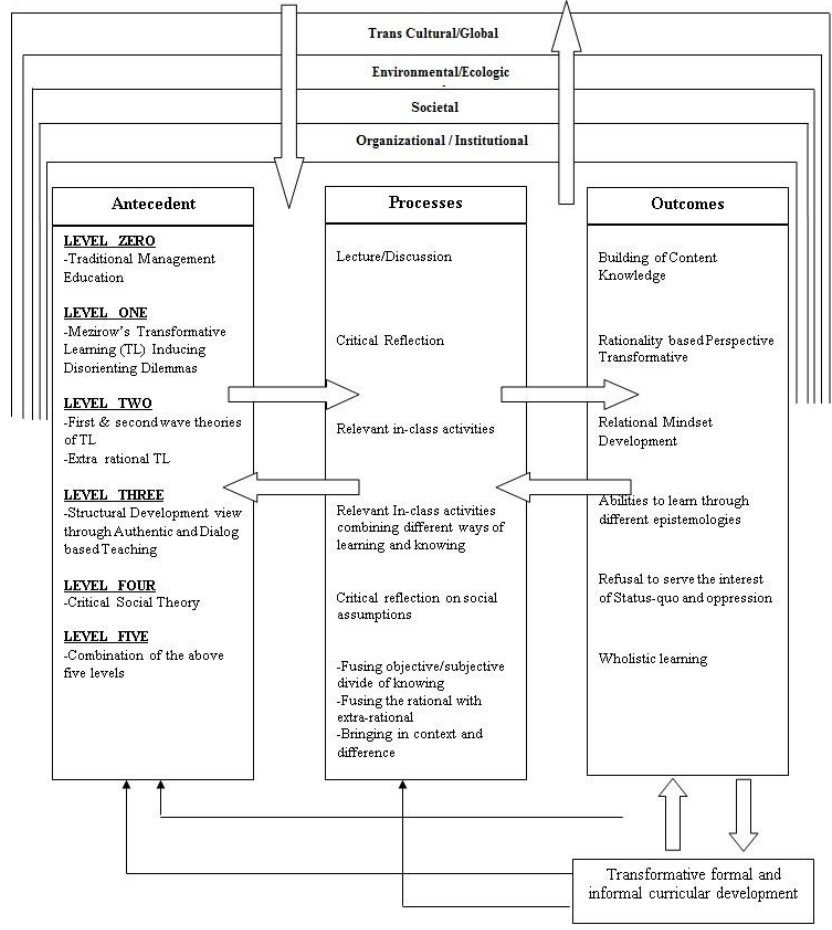

Figure 1: Wholistic Management Education Model

Sukkur IBA Journal of Management and Business | Volume 4 No. 1 January - June 2017 @ Sukkur IBA University 
Naveed Yazdani et. al. / Wholistic Management Education (WME): Theorizing the Contextualized Applicability of

The horizontal arrows connect the model antecedents with processes (pedagogical) and outcomes. At the same time like other discourses the outcomes are not only shaped by processes and antecedents but also co-create and sustain the antecedents. These horizontal discursive interactions do not happen in isolation but are embedded in a particular localness and context which again shapes and gets shaped by the horizontal discursive patterns of management education discourse emerging in a particular business school. The vertical and horizontal discursiveness embedded in the model has the potential to generate different management education discourses for different contexts and thus freeing management education from value-neutral universality discussed in the first two sections.

The levels of WME model progresses from a lower to higher order learning as they are traced vertically downwards. They are different because they reflect different subdiscourses of management education. Level Zero represents traditional management education while Level 1 builds on it and adds Mezirow's rationality based critical reflection (largely absent from traditional management education) to it. Similarly, the other levels move from limited to more comprehensive learning encompassing epistemologies beyond objectivism and incorporating extra-rational spirituality and ability to employ critical social theory in solving management related issues. The highest level (Level 5) is the Wholistic level because it encompasses and entails all the other levels in it.

\section{Methodology}

Universities are places where knowledge discourses are formed because it is here that knowledge, society and culture interact. Business schools are located at the interface of this interconnectedness (Pettigrew \& Starkey, 2016) and therefore ideal institutions where management education discourse embedded in cultural, political and societal contexts is shaped. This is why Discourse is utilized as 'bridge' between the earlier sections and the following Discussion section.

Viewing management education as a discourse and business schools as institutions legitimizing and solidifying this discourse is consistent with Phillips, (Lawrence et al., 2012) widely cited work Discourse and Institutions which portrays a mutually constitutive relationship among organizational actors, different forms of texts, discourse and organizations. These relationships are envisaged to be present among faculty, students, administrators; formal and informal curricula (depicting the formal and informal texts used) and discursive patterns taking shape within the context of business schools. The following Figure 2 depicts these relationships between actions and discourse in the backdrop of management education imparting institutions. Adapted from Phillips, (Lawrence and Hardy, 2004).

Sukkur IBA Journal of Management and Business | Volume 4 No. 1 January - June 2017 @ Sukkur IBA University 
Naveed Yazdani et. al. / Wholistic Management Education (WME): Theorizing the Contextualized Applicability of

Conversational such as lectures, discussions, seminars and, training sessions or written like academic journals, books and manuals. The upward diagonal arrows of the above Figure show how actions of the actors through producing various kinds and forms of texts impact the discursive patterns of a business school. Some of these texts are more durable and become embedded in the existing or new discourse. Since discourses constitute the social reality of business school, they impact and shape the actions that

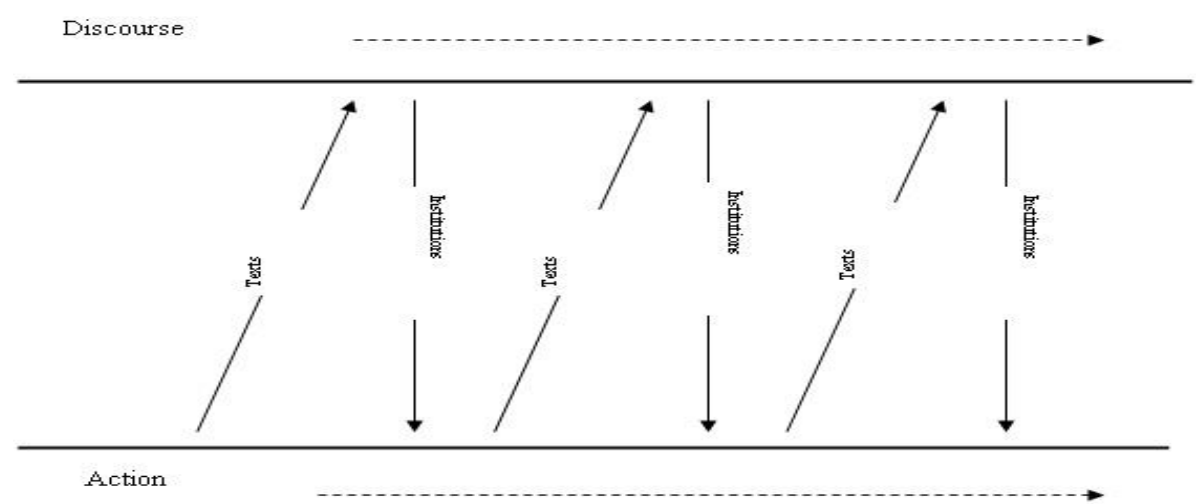

Figure 2: The relationship between Action and Discourse of a Business School

produce more and new texts. The vertical downward arrows of the above Figure show how discursive patterns affect action and in doing so create the social reality of business school as an institution.

Other discourse scholars (Fairclough, 1992; Fairclough \& Wodak, 1995; Hodges, 2015; Van Dijk, 1997) identify the following key characteristics of Discourse Analysis (DA):

1. Focus on collection of bodies of texts rather than isolated and individual texts

2. The intertextuality or interwoven nature of texts and discourses and the support from broader discourse within which a particular discourse can be located

3. The audience to whom discourses are disseminated

4. The legitimacy of their production through re-contextualized social actions so that only those actions are retained in discourse which are procedural, regimented and regulated (Van Leeuwen, 2008)

5. Patterns of their reception and consumption

6. The linguistic focus and seeping in of 'ideologies' in discourses through language

7. Macro social or extra-linguistic factors of discourse such as institutional, societal and cultural practices

8. Strong interdisciplinary focus (de Melo Resende, 2013)

Sukkur IBA Journal of Management and Business | Volume 4 No. 1 January - June 2017 @ Sukkur IBA University 
Naveed Yazdani et. al. / Wholistic Management Education (WME): Theorizing the Contextualized Applicability of

Critical Discourse Analysis (CDA) is DA done with a critical slant and analyses the way "social power abuse and inequality are enacted, reproduced, legitimated and resisted by text and talk in the social and political contexts" (Van Dijk, 1997). CDA dissects both micro (language use, verbal interaction) and macro (power, inequality, hegemony between different social groups) levels of social order (Fairclough \& Wodak, 1995; Wodak \& Meyer, 2009).

CDA also highlights how concepts are reified and legitimized and operationalized when technical jargon or dominant regulatory mechanisms hinder real representation of an entity, phenomena or concept like organizations (Barbera et al., 2015; Krzyzanowski, 2010).

\section{Discussion}

In natural sciences models serve as main tools for explicating chosen aspects of the universe for serving different objectives of scientific inquiry (Seelos, 2010). Models also play important role in social sciences by linking developing and developed theories with the observable world (Brante, 2010).

The wholistic management education (WME) model presented in this study is validated based on established criteria examining the adequacy of models. Contemporary scholars (Kaufman, 2012; Seelos, 2010; Seelos \& Mair, 2007) have identified certain standards to establish analytical, theoretical and ontological validity of business and theoretical models. These standards are entailed in the following questions employed to evaluate WME model:

1. Does the model adequately explain and describe the phenomenon of wholistic management education?

2. Which theories inform this model? Do the theory/model relationships come out clearly?

3. Do the model/world relationships come out clearly?

4. Is the model aligned with research methodology of the paper?

The model describes the evolution of wholistic management education as Level 5 transformative management education. Level 1 TME tops up traditional management education (Level Zero TME) with Mezirow's rationality based transformative learning theory. Level 2 TME builds on the previous level and incorporates first and second waves of transformative learning theory and its main stay is extra-rationality. The spiritual, mystical, linguistic and political discourses are allowed to become part of the value-neutral rational discourse of management education. Level 3 TME ensure that the learners are not exposed to one dominant way of knowing while critique on taken for granted societal and cultural assumptions is the main outcome of Level 4 TME discourse which employs critical social theory based pedagogies. The critical social theory of this Level primarily questions, challenges and problematizes assumption that

Sukkur IBA Journal of Management and Business | Volume 4 No. 1 January - June 2017 @ Sukkur IBA University 
Naveed Yazdani et. al. / Wholistic Management Education (WME): Theorizing the Contextualized Applicability of

societies of Western civilization are free and democratic. It is to be noted that Level IV WME does not just expose faculty and students to yet another critical theory but to the skills which equip them to adopt a mind-set labelled 'evolving criticality' by (Kincheloe, McLaren, \& Steinberg, 2011). This mind set is underpinned by inculcation of a set of fundamental assumptions which include: thoughts are historically and socially constructed and embedded by power relations mostly emanating from social relations of capitalistic consumption and production, language is crucial in creating social reality, acceptance of the oppressed of their subordinated status as natural and inevitable, focusing on multiple faces of oppression (class, gender, religion, race and more) and that dominant management educational and research discourse reproduces most forms of oppressions mentioned above.

Level 5 TME is WME which includes all the four levels of TME and combines multiple epistemologies to attain wholistic learning and, rational and extra-rational pedagogical discourses to restore the whole self which facilitates full development of students' identity.

The above brief description shows that the model explains and describes the notion of WME in a clear way.

\subsection{The Theory/Model Relationships}

The main aim of theoretical adequacy is to focus on how theories and models are linked and which theoretical elements are incorporated in the model. Through its levels the WME model clearly identifies that it is aligned with four major perspectives of transformative learning theory. Level 5 is the highest level combining the practice of traditional management education theories with other levels. The model also connects these perspectives with class processes and outcomes and the broader contexts of society, culture and environment. The model is therefore theoretically adequate.

\subsection{The Model/World Relationships}

The main motive of the model is to ensure that management education is not one sided but wholistic in nature. That is why the model builds its tone from Mezirow's transformative learning theory and terms it Level $1 \mathrm{TME}$ and moves vertically towards Level 5. The model is an attempt to create wholeness in management education by achieving transformation at personal level. The full identity of the students is envisaged to emerge as a psychosocial reflexive process which the model captures by showing reflexive linkages between a management education imparting university, organizations, society and, the overall environment at national and transnational levels. But creating this wholeness through reflexive relations is invisible, unstated and intangible. This is what (Caza \& Brower, 2015) call the informal curriculum which they consider more suitable to lead to change and transformation. WME encompasses both formal and informal curricula which are embedded in the explicit and implicit culture

Sukkur IBA Journal of Management and Business | Volume 4 No. 1 January - June 2017 @ Sukkur IBA University 
Naveed Yazdani et. al. / Wholistic Management Education (WME): Theorizing the Contextualized Applicability of

of a business school which it intends to nurture. The model therefore is located very much in the real world of management education imparting business schools. Its aims and objectives however look beyond the traditional and standard utilitarian management education which seeks to produce technically skilled personnel without giving much importance to the emotional, spiritual, imaginative aspects and building a long-term focus of injecting 'wise' men and women in the society.

\subsection{Model and Research Methodology}

A comparison of WME model with Figure 2 of research methodology yields interesting common points. TME Level 0 or traditional management education produces verbal and written texts which train students to take specific managerial actions when they are employed in organizations. The organizational discourse retains these actions because they are consistent with the 'legitimate' procedures and way of doing work in corporations. The corporate practices affect society. Over the years management education texts and organizational actions have produced specific societal actions like consumerism, over consumption and over spending and, blind acceptance and legitimization of media commercials and branding practices. These actions are retained in the society to produce a 'corporate discourse' which 'legitimizes' the actions and texts of business schools. In this way the business school, corporate and societal discourses co-create one another. This is how WME model explains and predicts discursive patterns created in society and business schools when traditional management education texts are the only ones taught and talked about at business schools.

The types of discursive organizational and societal practices and discourses are produced if texts based on TME Level 1,2,3 and 4 are made part of business school education are not difficult to imagine. Similarly the WME will lead to very different organizational and societal discourses and actions. The intertextuality or inextricable interwoven nature of different texts and discourses (Hodges, 2015) and discursiveness inherent in WME model aligns it very well with research methodology of DA and CDA.

\subsection{Application of CDA}

A very brief discussion of CDA of traditional management education now follows.

The Introduction section of this paper highlights four major themes of traditional management education which are scrutinized by some of the extra-linguistic elements of CDA identified in the Methodology section. This is in accordance with the inherent historicity in discourses rendering them to interpretation in terms of references to society, culture and ideology (Wodak \& Meyer, 2009).

The first theme is that management education is not based on real world's problems. The technical jargon and concepts of management education (like strategy) are reified

Sukkur IBA Journal of Management and Business | Volume 4 No. 1 January - June 2017 @ Sukkur IBA University 
Naveed Yazdani et. al. / Wholistic Management Education (WME): Theorizing the Contextualized Applicability of

to the extent that they become legitimized concepts. These operationalized concepts remove management students from the real complex and fuzzy world of business. This practice is in contrast to medical and law education (Ungaretti et al., 2015) because in their case the education does not just present factual knowledge to students but problematize it so that they solve real world problems on real world issues (patients or legal cases).

The second theme highlights the westernization of management education and its excessively value-neutral, universal and scientific orientation. This is how management education legitimizes Western societal and cultural values in non-Western cultures. The hegemony thus created is so subtle and natural that the other cultures form dialectical relations with the west to whom they look for generating texts and organizational actions and practices which become embedded in their own social discourses.

The third major theme is that of 'unwise' and too much short term focus on means and not ends. This tendency promotes power asymmetries, abuse and exploitation because material wealth and success become standards of gauging life success. Wisdom, longterm view and focus on extra-rationality take a back seat in the societal discourse. Management education imparting business schools sacrifice interdisciplinary approach because they find no need to engage humanities, arts, spirituality, history and religion in their discourses. That adds to the emotional blandness, soullessness and one track intelligence of their graduates.

The fourth major theme emerging from Introduction is the lack of critical reflection focus in management education. When taken for granted assumptions about self and society are not challenged, it becomes impossible to break the iron hold of status quo and the power imbalance and inequalities embedded in it.

\subsection{Future Direction}

\subsubsection{Linguistic analysis of traditional management texts/discourse}

Linguistic analysis of management texts was beyond the scope of this paper. It can however become an interesting future research area to be explored by employing DA on verbal and written management texts.

\subsubsection{Flexibility and generalizability of WME model}

In the tradition of (Yazdani \& Murad, 2015) model of ethicality, the proposed WME model is not prescriptive and does not promote any particular form of universal management education. On the contrary it promotes contextualized management education. This model can be equally effectively applied across cultures because it fully embraces and allows for localness, Contextuality and local values and norms. The simultaneous generalizability and flexibility of the model will emerge as it is put in practice in different contexts by researchers and practitioners.

Sukkur IBA Journal of Management and Business | Volume 4 No. 1 January - June 2017 @ Sukkur IBA University 
Naveed Yazdani et. al. / Wholistic Management Education (WME): Theorizing the Contextualized Applicability of

\subsubsection{Scope for empirical research}

Mezirow's transformative learning theory has not been empirically tested in the context of most non-Western settings. It would be a useful practice because it will provide a new angle and perspective to the already existing rich body of literature on transformative learning. There are many constructs of WME model such as TME Levels and WME for which instruments can be developed for empirical testing. More qualitatively oriented research techniques such as phenomenology would also add rich insights from different perspective in the existing body of knowledge of transformative learning theory. Mezirow's transformative learning theory has not been empirically tested in the context of most non-Western settings. It would be a useful practice because it will provide a new angel and perspective to the already existing rich body of literature on transformative learning. There are many constructs of WME model such as TME Levels and WME for which instruments can be developed for empirical testing. More qualitatively oriented research techniques such as phenomenology would also add rich insights from different perspective in the existing body of knowledge of transformative learning theory.

\subsubsection{Moving towards a unified theory of transformative learning}

Transformative learning is explored outside the North American context in European, Far Eastern, African, Australian and South American settings. Exploring it in other contexts will give its literature more breadth because so far not much research on the construct has been conducted in the South East Asian and Middle Eastern context.

This paper provides more depth to already existing transformative learning knowledge by specifically focusing on its application in the context of management education. So far the theory is extensively studied in non-management settings like arts, literature, nursing, palliative care, medicine and psychology. Further research connecting transformative learning with management education would facilitate knowledge advancement by crafting more unified and context based transformative learning theory.

\section{References}

Agasisti, T., \& Johnes, G. (2015). Efficiency, costs, rankings and heterogeneity: the case of US higher education. Studies in Higher Education, 40(1), 60-82.

Arum, R., \& Roksa, J. (2011). Academically adrift: Limited learning on college campuses: University of Chicago Press.

Baden, D., \& Higgs, M. (2015). Challenging the perceived wisdom of management theories and practice. Academy of Management Learning \& Education, 14(4), 539-555.

Barbera, F., Bernhard, F., Nacht, J., \& McCann, G. (2015). The relevance of a wholeperson learning approach to family business education: Concepts, evidence,

Sukkur IBA Journal of Management and Business | Volume 4 No. 1 January - June 2017 @ Sukkur IBA University 
Naveed Yazdani et. al. / Wholistic Management Education (WME): Theorizing the Contextualized Applicability of

and implications. Academy of Management Learning \& Education, 14(3), 322346.

Bennis, W. G., \& O'Toole, J. (2005). How business schools lost their way. Harvard business review, 83(5), 96-104.

Brante, T. (2010). Review essay: perspectival realism, representational models, and the social sciences. Philosophy of the Social Sciences, 40(1), 107-117.

Bredo, E., \& Feinberg, W. (1982). Knowledge and values in social and educational research.

Brookfield, S., \& Mezirow, J. (2000). Learning as transformation: Critical perspectives on a theory in progress: San Francisco, Jossey Bass.

Byron, K., \& Thatcher, S. M. (2016). Editors' comments:"What I know now that I wish I knew then"-Teaching theory and theory building. Academy of Management Review, 41(1), 1-8.

Carlile, P., Nicolini, D., Langley, A., \& Tsoukas, H. (2013). Introducing the third volume of" Perspectives on organization studies. How matter matters: Objects, artifacts and materiality in organization studies, 1-15.

Caza, A., \& Brower, H. H. (2015). Mentioning the unmentioned: An interactive interview about the informal management curriculum. Academy of Management Learning \& Education, 14(1), 96-110.

Coryell, J. E. (2013). Collaborative, comparative inquiry and transformative crosscultural adult learning and teaching: A western educator metanarrative and inspiring a global vision. Adult Education Quarterly, 63(4), 299-320.

Cranton, P., \& Carusetta, E. (2004). Perspectives on authenticity in teaching. Adult Education Quarterly, 55(1), 5-22.

Currie, R. R., \& Pandher, G. (2013). Management education journals' rank and tier by active scholars. Academy of Management Learning \& Education, 12(2), 194218.

Daloz, L. A. (2012). Mentor: Guiding the Journey of Adult Learners (with New Foreword, Introduction, and Afterword): John Wiley \& Sons.

de Melo Resende, V. (2013). Critical discourse analysis and ethnography: the crisis in the national street children's movement in Brazil. Qualitative Research, 13(5), 511-527.

Dirkx, J. M. (1998). Transformative learning theory in the practice of adult education: An overview. PAACE journal of lifelong learning, 7, 1-14.

Fairclough, N. (1992). Discourse and social change.

Fairclough, N., \& Wodak, R. (1995). Critical discourse analysis.

Fisher-Yoshida, B., Geller, K. D., \& Schapiro, S. A. (2009). Innovations in transformative learning: Space, culture, \& the arts (Vol. 341): Peter Lang.

Freire, P. (1970). Pedagogy of the Oppressed (New York. Continuum, 72.

Gardner, M., \& Kelly, U. (2008). Narrating transformative learning in education: Springer. 
Naveed Yazdani et. al. / Wholistic Management Education (WME): Theorizing the Contextualized Applicability of

Ghoshal, S. (2005). Bad management theories are destroying good management practices. Academy of Management Learning \& Education, 4(1), 75-91.

Gunnlaugson, O. (2008). Metatheoretical prospects for the field of transformative learning. Journal of Transformative Education, 6(2), 124-135.

Habermas, J. (1978). Knowledge and human interests.

Habermas, J. (1984). The Theory of Communicative Action, vol. 1, Reason and the Rationalization of Society, trans. Thomas McCarthy. Boston: Beacon.

Hodges, A. (2015). Intertextuality in Discourse. The Handbook of Discourse Analysis, 42.

Hoover, J. D., Giambatista, R. C., Sorenson, R. L., \& Bommer, W. H. (2010). Assessing the effectiveness of whole person learning pedagogy in skill acquisition. Academy of Management Learning \& Education, 9(2), 192-203.

Illeris, K. (2014). Transformative learning and identity. Journal of Transformative Education, 12(2), 148-163.

Isopahkala-Bouret, U. (2015). Educational credentialing of an aging workforce: Uneasy conclusions. Adult Education Quarterly, 65(2), 83-99.

Jarvis, C., \& Burr, V. (2011). The transformative potential of popular television: The case of Buffy the Vampire Slayer. Journal of Transformative Education, 9(3), $165-182$.

Joullié, J.-E. (2016). The philosophical foundations of management thought. Academy of Management Learning \& Education, 15(1), 157-179.

Joullié, J.-E., \& Spillane, R. (2015). Heroic Drucker. Journal of Business Ethics, 128(1), 95-105.

Kagan, J. (2007). An argument for mind: Yale University Press.

Kaufman, B. E. (2012). Strategic human resource management research in the United States: A failing grade after 30 years? The Academy of Management Perspectives, 26(2), 12-36.

Kegan, R. (2009). What" form" transforms. A constructive-developmental approach to transformative learning. Teoksessa K. Illeris (toim.) Contemporary theories of learning: learning theorists in their own words. Abingdon: Routledge, 35-54.

Kincheloe, J. L., McLaren, P., \& Steinberg, S. R. (2011). Critical pedagogy and qualitative research. The SAGE handbook of qualitative research, 163-177.

Kokkos, A. (2014). Could transformative learning be appreciated in Europe? Journal of Transformative Education, 12(2), 180-196.

Krzyzanowski, M. (2010). The discursive construction of European identities. Peter Lang, Frankfurt am Main.

Lawrence, R., Taylor, E., \& Cranton, P. (2012). Transformative learning through artistic expression: Getting out of our heads. The handbook of transformative learning: Theory, research, and practice, 471-485.

Liu, J. H. (2011). Asian epistemologies and contemporary social psychological research. The SAGE handbook of qualitative research, 213-226.

Sukkur IBA Journal of Management and Business | Volume 4 No. 1 January - June 2017 @ Sukkur IBA University 
Naveed Yazdani et. al. / Wholistic Management Education (WME): Theorizing the Contextualized Applicability of

Mayo, M., Kakarika, M., Pastor, J. C., \& Brutus, S. (2012). Aligning or inflating your leadership self-image? A longitudinal study of responses to peer feedback in MBA teams. Academy of Management Learning \& Education, 11(4), 631-652.

Merriam, S. B., \& Mohamad, M. (2000). How cultural values shape learning in older adulthood: The case of Malaysia. Adult Education Quarterly, 51(1), 45-63.

Merriam, S. B., \& Ntseane, G. (2008). Transformational learning in Botswana: How culture shapes the process. Adult Education Quarterly, 58(3), 183-197.

Mezirow, J. (1985). Concept and action in adult education. Adult Education Quarterly, $35(3), 142-151$.

Mezirow, J. (1989). Transformation theory and social action: A response to Collard and Law. Adult Education Quarterly, 39(3), 169-175.

Mezirow, J. (1991). Transformative dimensions of adult learning: ERIC.

Mezirow, J. (1994). Understanding transformation theory. Adult Education Quarterly, 44(4), 222-232.

Mezirow, J. (1996). Contemporary paradigms of learning. Adult Education Quarterly, 46(3), 158-172.

Mezirow, J. (1997). Transformative learning: Theory to practice. New directions for adult and continuing education, 1997(74), 5-12.

Mezirow, J. (2000a). Learning as Transformation: Critical Perspectives on a Theory in Progress. The Jossey-Bass Higher and Adult Education Series: ERIC.

Mezirow, J. (2000b). Learning to think like an adult. Learning as transformation: Critical perspectives on a theory in progress, 3-33.

Mezirow, J. (2003). Transformative learning as discourse. Journal of Transformative Education, 1(1), 58-63.

Mezirow, J. (2006). An overview on transformative learning. Lifelong learning: Concepts and contexts, 24-38.

Mezirow, J., \& Marsick, V. (1978). Education for Perspective Transformation. Women's Re-entry Programs in Community Colleges.

Mezirow, J., \& Taylor, E. W. (2011). Transformative learning in practice: Insights from community, workplace, and higher education: John Wiley \& Sons.

Mintzberg, H. (2004). Managers, not MBAs: A hard look at the soft practice of managing and management development: Berrett-Koehler Publishers.

Morris, A. H., \& Faulk, D. R. (2012). Transformative learning in nursing: A guide for nurse educators: Springer Publishing Company.

Newman, M. (2012). Calling transformative learning into question: Some mutinous thoughts. Adult Education Quarterly, 62(1), 36-55.

Nicolaides, A. (2015). Generative learning: Adults learning within ambiguity. Adult Education Quarterly, 65(3), 179-195.

O’Sullivan, E., Taylor, E., \& Cranton, P. (2012). Deep transformation: Forging a planetary worldview. The handbook of transformative learning: Theory, research, and practice, 162-177.

Sukkur IBA Journal of Management and Business | Volume 4 No. 1 January - June 2017 @ Sukkur IBA University 
Naveed Yazdani et. al. / Wholistic Management Education (WME): Theorizing the Contextualized Applicability of

Parker, L. D., \& Guthrie, J. (2010). Business schools in an age of globalization. Accounting, Auditing \& Accountability Journal, 23(1), 5-13.

Pettigrew, A., \& Starkey, K. (2016). From the Guest Editors: The Legitimacy and Impact of Business Schools-Key Issues and a Research Agenda. Academy of Management Learning \& Education, 15(4), 649-664.

Pfeffer, J. (2013). You're still the same: Why theories of power hold over time and across contexts. The Academy of Management Perspectives, 27(4), 269-280.

Plaskoff, J. (2012). Building the heart and the mind: An interview with leading social entrepreneur Sarah Harris. Academy of Management Learning \& Education, $11(3), 432-441$.

Rynes, S. L., \& Brown, K. G. (2011). Where are we in the "long march to legitimacy?" Assessing scholarship in management learning and education. Academy of Management Learning \& Education, 10(4), 561-582.

Sandberg, J., \& Tsoukas, H. (2011). Grasping the logic of practice: Theorizing through practical rationality. Academy of Management Review, 36(2), 338-360.

Seelos, C. (2010). Theorizing and strategizing with models: Generative models of business models.

Seelos, C., \& Mair, J. (2007). Profitable business models and market creation in the context of deep poverty: A strategic view. The Academy of Management Perspectives, 21(4), 49-63.

Slater, D. J., \& Dixon-Fowler, H. R. (2010). The future of the planet in the hands of MBAs: An examination of CEO MBA education and corporate environmental performance. Academy of Management Learning \& Education, 9(3), 429-441.

Stevens-Long, J., Schapiro, S. A., \& McClintock, C. (2012). Passionate scholars: Transformative learning in doctoral education. Adult Education Quarterly, 62(2), 180-198.

Szkudlarek, B., McNett, J., Romani, L., \& Lane, H. (2013). The past, present, and future of cross-cultural management education: the educators' perspective. Academy of Management Learning \& Education, 12(3), 477-493.

Taylor, C. (2007). A secular age: Harvard University Press.

Taylor, E. W. (1997). Building upon the theoretical debate: A critical review of the empirical studies of Mezirow's transformative learning theory. Adult Education Quarterly, 48(1), 34-59.

Taylor, E. W. (2007). An update of transformative learning theory: A critical review of the empirical research (1999-2005). International journal of lifelong education, 26(2), 173-191.

Taylor, E. W., \& Cranton, P. (2012). The handbook of transformative learning: Theory, research, and practice: John Wiley \& Sons.

Tisdell, E. J. (2000). Spirituality and emancipatory adult education in women adult educators for social change. Adult Education Quarterly, 50(4), 308-335.

Sukkur IBA Journal of Management and Business | Volume 4 No. 1 January - June 2017 @ Sukkur IBA University 
Naveed Yazdani et. al. / Wholistic Management Education (WME): Theorizing the Contextualized Applicability of

Tisdell, E. J. (2012). Themes and variations of transformational learning: Interdisciplinary perspectives on forms that transform. The handbook of transformative learning: Theory, research, and practice, 21-36.

Ungaretti, T., Thompson, K. R., Miller, A., \& Peterson, T. O. (2015). Problem-based learning: Lessons from medical education and challenges for management education. Academy of Management Learning \& Education, 14(2), 173-186.

Van Dijk, T. A. (1997). The study of discourse. Discourse as structure and process, 1, $1-34$.

Van Leeuwen, T. (2008). Discourse and practice: New tools for critical discourse analysis: Oxford University Press.

Willmott, H. (2013). Reflections on the darker side of conventional power analytics. The Academy of Management Perspectives, 27(4), 281-286.

Wodak, R., \& Meyer, M. (2009). Methods for critical discourse analysis: Sage.

Yazdani, N., \& Murad, H. S. (2015). Toward an ethical theory of organizing. Journal of Business Ethics, 127(2), 399-417.

Zohar, D. (1990). Quantum Self: Human Nature and Consciousness. Morrow, New York. 